\title{
History of metal contamination in Lake Illawarra, NSW, Australia
}

\author{
Larissa Schneider $^{\mathrm{a}, *}$, William Maher ${ }^{\mathrm{a}}$, Jaimie Potts ${ }^{\mathrm{a}, \mathrm{b}}$, Graeme Batley ${ }^{\mathrm{c}}$, Anne Taylor ${ }^{\mathrm{a}}$, Frank Krikowa ${ }^{\mathrm{a}}$, \\ Anthony Chariton ${ }^{c}$, Atun Zawadzki ${ }^{\mathrm{d}}$, Henk Heijnis ${ }^{\mathrm{d}}$, Bernd Gruber ${ }^{\mathrm{a}}$ \\ anstitute for Applied Ecology, University of Canberra, Bruce, Canberra, ACT 2601, Australia \\ ${ }^{\mathrm{b}}$ Office of Environment and Heritage, Lidcombe, NSW 2141, Australia \\ c CSIRO Land and Water, Lucas Heights, NSW 2234, Australia \\ ${ }^{\mathrm{d}}$ Institute for Environmental Research, Australian Nuclear Science and Technology Organisation, Lucas Heights, NSW 2234, Australia
}

\section{H I G H L I G H T S}

- Lake Illawarra has a history of metal contamination.

- Metal concentrations were higher at the site closest to Port Kembla.

- The metals of highest concern were zinc and copper.

\section{A R T I C L E I N F O}

\section{Article history:}

Received 30 January 2014

Received in revised form 18 June 2014

Accepted 19 June 2014

Available online 23 July 2014

Handling Editor: J. de Boer

\section{Keywords:}

Estuarine lake

Cs

Metals

Port Kembla

Sediment dating

\begin{abstract}
A B S T R A C T
Lake Illawarra has a long history of sediment contamination, particularly by metals, as a result of past and current industrial operations and land uses within the catchment. In this study, we examined the history of metal contamination in sediments using metal analysis and ${ }^{210} \mathrm{~Pb}$ and ${ }^{137} \mathrm{Cs}$ dating. The distributions of copper, zinc, arsenic, selenium, cadmium and lead concentrations within sediment cores were in agreement with historical events in the lake, and indicated that metal contamination had been occurring since the start of industrial activities in Port Kembla in the late 1800s. Most metal contamination, however, has occurred since the 1960s. Sedimentation rates were found to be $0.2 \mathrm{~cm} \mathrm{year}^{-1}$ in Griffins Bay and $0.3 \mathrm{~cm}$ year $^{-1}$ in the centre of the lake. Inputs from creeks bringing metals from Port Kembla in the northeast of the lake and a copper slag emplacement from a former copper refinery on the Windang Peninsula were the main sources of metal inputs to Lake Illawarra. The metals of highest concern were zinc and copper, which exceeded the Australian and New Zealand sediment quality guideline values at some sites. Results showed that while historical contamination persists, current management practices have resulted in reduced metal concentrations in surface sediments in the depositional zones in the centre of the lake.
\end{abstract}

(c) 2014 Elsevier Ltd. All rights reserved.

\section{Introduction}

In Australia, $80 \%$ of the population is currently living in areas near estuaries, bays and harbours (Andutta et al., 2013), resulting in significant human impacts on coastal aquatic environments (Harvey and Caton, 2010). Understanding the history of metal inputs in coastal areas is, therefore, important for the protection and management of estuaries and many other coastal features.

The Illawarra region in New South Wales (NSW), Australia, is noted for its abundance of coal and water resources (Eklund, 2002). Wollongong, the regional centre, has become an important industrial centre in Australia with associated environmental problems related to metals released to the environment from the

\footnotetext{
* Corresponding author. Tel.: +61 429088813.

E-mail address: Larissa.Schneider@canberra.edu.au (L. Schneider).
}

production of steel, copper refining and burning of coal, such as lead, mercury, cadmium, arsenic, zinc, copper and selenium (Chenhall et al., 1995; Payne et al., 1997).

Lake Illawarra, an estuarine lake situated at the southern end of the City of Wollongong has faced high environmental pressures because of these industrial activities (Chenhall et al., 1995). This lake is in close proximity to Australia's largest steelworks at Port Kembla and is also close to a major copper smelter and refinery, closed in 1995 after almost a century of operation. On the western shores of Lake Illawarra is a coal-fired power station, which has been operating since 1954 with some intermittent periods of closure. In 2009, it was converted to gas-fired power operation. In addition, Lake Illawarra is at the centre of an area of significant residential development (Chenhall et al., 1994).

An effective way to understand the contaminant inputs and sources into lakes is to measure the history of contamination using 
sediment records (Kilby and Batley, 1993; Hollins et al., 2011). Once the history of contamination is reconstructed in the lake, it is then possible to determine how industrialization has affected the area. For convenience, both metals and metalloids in this study will be referred as metals.

In this study, we investigated the patterns of metal accumulation in sediments in Lake Illawarra over the past 80 years, which encompasses the time Port Kembla industry has been in operation. Metal concentration profiles in sediments have been previously measured in Lake Illawarra (Ellis and Kanamori, 1977; Chenhall et al., 1994, 2004; Gillis and Birch, 2006), but there is no information about selenium and arsenic concentrations, major elements found in Australian black coals. In addition, these studies used different dating techniques with limited use of proxies for crosschecking data. This study sought to: (i) measure concentrations of copper, arsenic, selenium, zinc, cadmium and lead in sediment cores, the metals found in Australian coal (Dale, 2006) and released from the existing industries adjacent to the lake; (ii) use ${ }^{210} \mathrm{~Pb}$, ${ }^{137} \mathrm{Cs}$ and sedimentation rates to understand spatial changes in metal concentrations; (iii) understand to what extent the various industries have contributed metals to the lake.

\section{Methods}

\subsection{Historical setting}

Lake Illawarra is a coastal lagoon located $10 \mathrm{~km}$ south of Wollongong (Fig. 1). It is a relatively shallow lake, with an average depth of $1.9 \mathrm{~m}$ and its deepest point being $3.7 \mathrm{~m}$ (Yassini and Jones, 1987). The lake is connected to the ocean by a narrow tidal channel approximately $2.4 \mathrm{~km}$ long, with a micro-tidal environment and low current velocities resulting in restricted lake-ocean water exchange (Chenhall et al., 1994). This lake was chosen for this study as it is one of Australian estuaries most affected by industries (Chenhall et al., 1994).
The northern hinterland of the lake is the site of the Port Kembla industrial complex (Fig. 1), including Bluescope (BHP) Steel (which started production in 1928), Port Kembla Copper (PKC) refining and smelting plant (which started production in 1910 and closed in August 2003), coal and grain handling facilities, and chemical fertiliser works (Chenhall et al., 2004). The majority of these industries are in close proximity to Lake Illawarra. It has been reported that two creeks draining sub-catchments associated with Port Kembla, Minnegang and Wegit Creeks, may be the source of metals from the industrial complex (Gillis and Birch, 2006). In addition, the Windang Peninsula was the site of a large deposition of copper slag at around $200-500 \mathrm{~m}$ from the foreshore of Lake Illawarra (Fig. 1).

Tallawarra Power Station on the western foreshore of the Lake (Fig. 1) commenced operation in 1954, reaching full operation by 1961. At its peak, it had a capacity of $320 \mathrm{MW}$ from four $30 \mathrm{MW}$ and two $100 \mathrm{MW}$ coal burning units. The station closed in 1989 , and stood abandoned until 2003, when it was sold by Pacific Power to TRUenergy and recommissioned as a gas-powered combined cycle plant (Energy Australia, 2013). Tallawarra ash dam, located adjacent to Duck Creek, was used as the dumping ground for ash from the power station in the last years of operation between 1983 and 1989 (TRUenergy Tallawarra, 2005).

\subsection{Sediment collection}

Sediment cores were collected from eight sites in Lake Illawarra based on their proximity to potential metal sources established from previous studies (Chenhall et al., 1994). At each location, two replicate cores were collected in order to obtain average profiles and check that the sediment profiles were not disturbed by collection procedures or by local human activities. Replicate cores were collected at a distance of $1 \mathrm{~m}$ apart.

Sediment cores were collected using acid-washed polyvinylchloride (PVC) tubes. After retrieval, the cores were maintained in a vertical orientation and a steel plunger used to push the

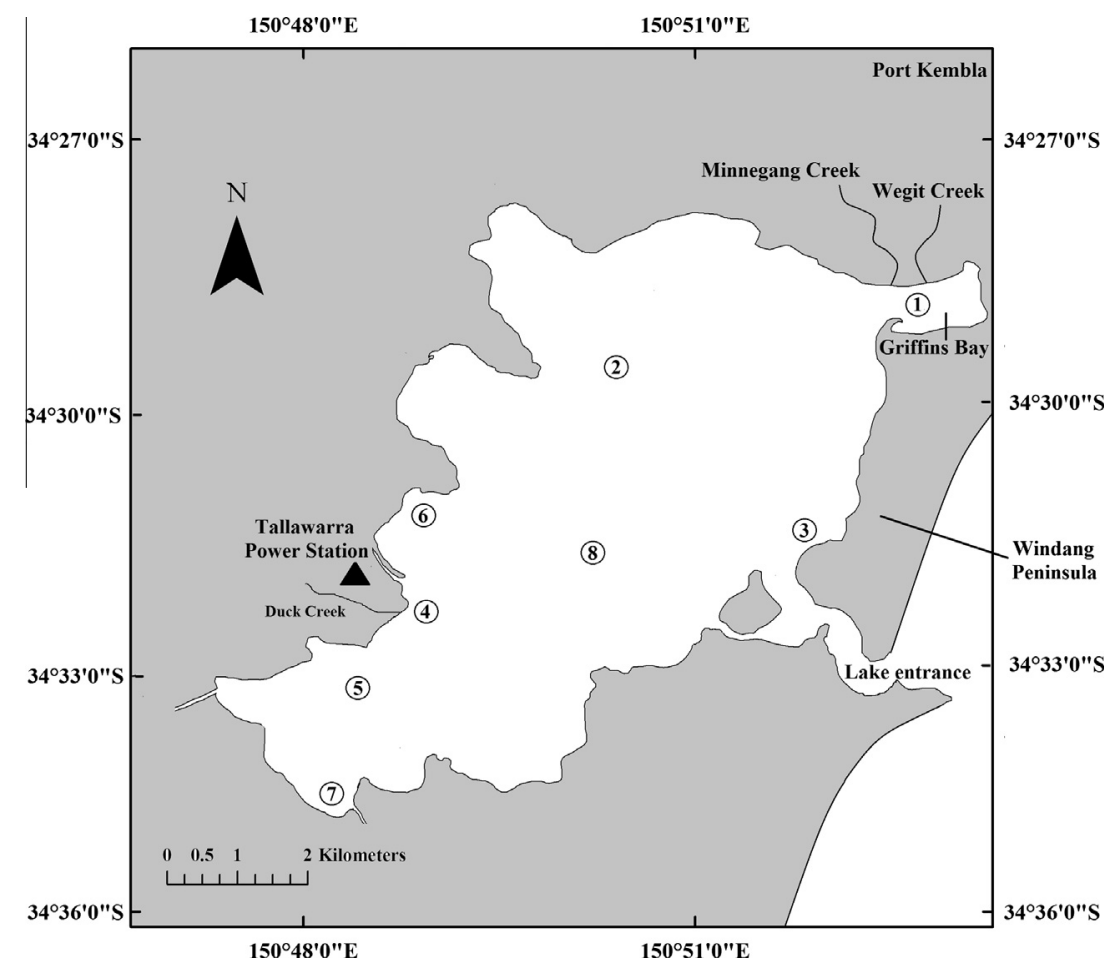

Fig. 1. Sample locations in Lake Illawarra, NSW, Australia. The black triangle represents the location of the Tallawarra Power Station ash dam. 
sediment up to the top part of the tube. The $15 \mathrm{~cm}$ deep cores were sliced every $3 \mathrm{~cm}$ using a stainless-steel spatula and ruler. Sediments were stored in zip-lock plastic bags at $4{ }^{\circ} \mathrm{C}$ until analysis.

\subsection{Metal analysis}

Cores from sites 1 and 8 were chosen for dating analysis as site 1 was expected to reflect Port Kembla inputs and site 8 to reflect deposition of copper slag on the lake foreshore leaching to the lake (Fig. 1).

Prior to metal analysis, all sediment core sections were freezedried for $72 \mathrm{~h}$. After drying, samples were placed into $200 \mathrm{~mL}$ tubes and homogenization of samples was performed by intensive manual mixing of sediment. Approximately $0.2 \mathrm{~g}$ of freeze-dried material was weighed into a $60 \mathrm{~mL}$ polytetrafluoroacetate (PFA) closed digestion vessel (Mars Express) and $2 \mathrm{~mL}$ of concentrated nitric acid (Aristar, BDH, Australia) and $1 \mathrm{~mL}$ of $30 \%$ concentrated hydrochloric acid (Merck Suprapur, Germany) added (Telford et al., 2008). Each PFA vessel was then capped, placed into a $800 \mathrm{~W}$ microwave oven (CEM model MDS-81, Indian Trail, NC, USA), and samples heated at $120^{\circ} \mathrm{C}$ for at least $15 \mathrm{~min}$. The diluted digests were cooled to room temperature and diluted to $50 \mathrm{~mL}$ with deionised water (Sartorius). The tubes were then centrifuged at $5000 \mathrm{rpm}$ for $10 \mathrm{~min} .1 \mathrm{~mL}$ of the digest was transferred into a $10 \mathrm{~mL}$ centrifuge tube and then diluted to $10 \mathrm{~mL}$ with ICP-MS internal standard $\left(\mathrm{Li}^{6}, \mathrm{Y}^{19}, \mathrm{Se}^{45}, \mathrm{Rh}^{103}, \mathrm{In}^{116}, \mathrm{~Tb}^{159}\right.$ and $\left.\mathrm{Ho}^{165}\right)$. Digests were stored $\left(0-5^{\circ} \mathrm{C}\right)$ until analysis. Samples were analysed for metals using inductively coupled plasma mass spectrometry (ICP-MS) (Perkin-Elmer DRC-e) with an AS-90 auto-sampler (Maher et al., 2001). Selenium concentrations were cross checked on a Perkin-Elmer 5100 Zeeman graphite furnace atomic absorption spectrometer, with an AS-60 auto-sampler, using a mixture of palladium and magnesium as the matrix modifier (Deaker and Maher, 1995).

For every 36 samples, two CRMs and two blanks were used. The certified reference materials NRC-BCSS1, NRC-Mess1, NIST-1646, NRC-PACS1 were used to check the accuracy of metal analysis. Metal concentrations were in agreement with certified values (Supplementary Table 1).

\subsection{Dating analysis}

The sediments were dated using ${ }^{137} \mathrm{Cs}$ and ${ }^{210} \mathrm{~Pb}$ methods. The total ${ }^{210} \mathrm{~Pb}$ activity in sediments has two components: supported ${ }^{210} \mathrm{~Pb}$ activity $\left({ }^{210} \mathrm{~Pb}_{\mathrm{s}}\right)$ which derives from the decay of in situ radium-226 $\left({ }^{226} \mathrm{Ra}\right)$, and unsupported ${ }^{210} \mathrm{~Pb}$ activity $\left({ }^{210} \mathrm{~Pb}_{\mathrm{u}}\right)$ which derives from atmospheric fallout. ${ }^{210} \mathrm{~Pb}_{\mathrm{s}}$ activity is determined indirectly via its grandparent radioisotope ${ }^{226} \mathrm{Ra}$. ${ }^{210} \mathrm{~Pb}_{\mathrm{u}}$ activity was estimated by subtracting ${ }^{210} \mathrm{Pbs}$ activity from the total activity of ${ }^{210} \mathrm{~Pb}\left({ }^{210} \mathrm{~Pb}_{\mathrm{t}}\right)$ or its progeny polonium-210 $\left({ }^{210} \mathrm{Po}\right)$.

The in situ production of supported ${ }^{210} \mathrm{~Pb}$ was measured indirectly from the activity of ${ }^{226} \mathrm{Ra}$ using gamma spectrometry. Unsupported ${ }^{210} \mathrm{~Pb}_{\mathrm{u}}$ cannot be measured directly and so was inferred from the activity of total ${ }^{210} \mathrm{~Pb}_{\mathrm{t}}$ minus the activity of supported ${ }^{210} \mathrm{~Pb}_{\mathrm{s}}$. The activity of total ${ }^{210} \mathrm{~Pb}_{\mathrm{t}}$ was determined by measuring ${ }^{210} \mathrm{~Pb}$ directly using gamma spectrometry.

Between 20 and $40 \mathrm{~g}$ of dried and ground whole sediment was analysed for ${ }^{137} \mathrm{Cs},{ }^{210} \mathrm{~Pb}$ and ${ }^{226} \mathrm{Ra}$ activities by Compton suppression gamma spectrometry. The detector system energy calibration was carried out using a National Institute of Standards and Technology (NIST) traceable multi-nuclide standard source and the detector system efficiency calibration was determined using IAEA reference materials including RGU-1, RGTh-1, RGK-1 and Soil-6.
Both the Constant Initial Concentration (CIC) and Constant Rate of Supply (CRS) models of ${ }^{210} \mathrm{~Pb}$ dating (Appleby and Oldfield, 1992) were used to construct chronologies for each of the sites, using the ${ }^{137} \mathrm{Cs}$ date as a reference point. Inflections in the ${ }^{210} \mathrm{~Pb}_{\mathrm{u}}$, activities profile usually reflect changes in sediment accumulation rate or bioturbation (Krantzberg, 1985). For those sites where the weight accumulation rate is fairly constant, i.e. where ${ }^{210} \mathrm{~Pb}_{\mathrm{u}}$, activity monotonically decreases with depth, the CIC and CRS models are usually in agreement. Where there is a non-monotonic trend in the ${ }^{210} \mathrm{~Pb}_{\mathrm{u}}$, depth profile, the use of the CIC model is usually precluded and the CRS model is used to calculate the chronology.

\subsection{Grain size analysis}

As the surface area of sediments is grain-size dependent and controls the adsorption of metals, metal concentrations were normalised to grain size in order to interpret metal concentrations in sediments between areas (Blomqvist et al., 1992; Hanson et al., 1993).

All sections of all cores were analysed for sediment grain size at the Australian Nuclear Science and Technology Organisation. Samples were first sieved to the particle size of $<2000 \mu \mathrm{m}$ (i.e. gravel-free) and, sediment fractions were determined using laser detection on a Malvern Mastersizer 2000 with a 300RF lens, $0.05-900 \mu \mathrm{m}$. Samples were dispersed in water and $30 \mathrm{~s}$ of ultrasonication was used to break up agglomerated particles. A total of three measurements were made for each sample and the average used as the final value. The distribution abundances within the $0.2-2000 \mu \mathrm{m}$ grain size range were calculated by the Malvern built-in software.

All sediments were classified to four classes: clay (particles with diameter $<2 \mu \mathrm{m})$, silt $(2-20 \mu \mathrm{m})$, fine sand $(20-200 \mu \mathrm{m})$ and coarse sand $(200-2000 \mu \mathrm{m})$. This classification was developed by McKenzie et al. (2000) and Carlile et al. (2001) to generate soil attribute surfaces for the Australian Soil Resource Information System.

In this study, normalisation of metal concentrations in sediments was performed using iron (Fe) following the method of Suh and Birch (2005). In this process of normalisation, the correlation between iron concentration and fine fraction (silt and clay) was the basis for normalisation. Clay content $(<20 \mu \mathrm{m})$ significantly predicted iron concentration in total sediment (grain size $<2000 \mu \mathrm{m})($ slope $=225.2, t(33)=4.14, p<0.001)$. Clay content percentage explained $34 \%$ of variance in iron concentrations in total sediments $\left(R^{2}=0.34, F(1,33)=17.22 ; p<0.001\right.$; Supplementary Fig. 1). Iron concentrations were corrected to the clay content by using the regression Eq. (2):

Normalised $\mathrm{Fe}=8820+(2252 \times$ clay content $)$

Metal concentration values in the sediment were normalised by multiplying a given metal concentration value by 10000 and dividing by the iron-normalised value. Normalised data were only used for comparisons of metal concentrations between sites. As grain size did not significantly change vertically within a core, the original non-normalised data were used in the interpretation of dating data in this study.

\subsection{Statistical analysis}

To compare the pattern of metal concentrations by sites and by sediment depths, a dissimilarity matrix was built and samples were tested using an Analysis of Similarities Test (ANOSIM) (Clarke, 1993). ANOSIM explicitly compares the level of similarity found in all pairs within each level of a factor against the similarity found in between-level pairs. Significance testing used randomizations (Legendre and Legendre, 2012). 
Specifically, this procedure was used to test the null hypothesis that there is no difference in metal concentrations in sediments between sites. If the $p$-value was less than 0.05 , then the null hypothesis was rejected and a $t$-test pairwise with Bonferroni correction was conducted at the level 0.05 based on dissimilarity ranks.

To visualise similarity between sites, multidimensional scaling (MDS) based on Euclidean distances was used.

All computations were performed using the software $R$ ( $R$ Development Core Team, 2013), using the package Vegan (version 2.0-7; URL: http://cran.r-project.org/web/packages/vegan/index. html). The graphs of profile cores were built using package Analogue (version 0.10-0; http://cran.r-project.org/web/packages/ analogue/index.html) and package Lattice (version 0.20-15 http:// cran.r-project.org/web/packages/lattice/index.html).

\section{Results}

\subsection{Metal concentration variation with depth}

Metal concentrations within sediment cores of the lake varied similarly within depth, except for site 1 which had great variability in metal concentration patterns with depth (Fig. 2).

Based on metal background concentrations previously reported for Lake Illawarra of $\mathrm{Zn}<87 \mathrm{mg} \mathrm{kg}^{-1}, \mathrm{Cu}<39 \mathrm{mg} \mathrm{kg}^{-1}$, $\mathrm{Cd}<1 \mathrm{mg} \mathrm{kg}^{-1}$ and $\mathrm{Pb}<19 \mathrm{mg} \mathrm{kg}^{-1}$ (Ellis and Kanamori, 1977; Gillis and Birch, 2006), in this study, non-normalised concentrations of copper, zinc and lead reached background concentrations within the sampled depth in cores from sites 2, 3 and 4 and cadmium reached background concentrations at all sites, except site 1 (Table 1). If considering background values in other nearby estuarine lakes (e.g. Lake Macquarie, Batley, 1987) of $<1 \mathrm{mg} \mathrm{Se} \mathrm{kg}{ }^{-1}$ and $<15 \mathrm{mg} \mathrm{As} \mathrm{kg}{ }^{-1}$, selenium reached background concentrations in the cores from sites $1,3,4,5$ and 6 , while arsenic reached background concentrations in cores from sites 1 to 7 (Table 1).

\subsection{Metal concentrations between sites}

The variation in metal concentrations between sites was clear and well defined (Figs. 2 and 3).

Dissimilarity rankings of normalised metal concentrations in sediment cores showed that there was a significant difference in metal concentrations between sites $(R=0.57, p=0.001)$. Pairwise comparisons (Table 2) and the MDS plot (Fig. 3) showed that site 1 was clearly different from the other sites, with higher metal concentrations. Site 3 had a peculiar trend in its metal concentration depth profile, but had concentrations similar to other sites with the exception of site 1 .

\subsection{History of anthropogenic metal contamination}

\subsubsection{Lake Illawarra core 1 replicate 1 (core 1.1)}

Unsupported ${ }^{210} \mathrm{~Pb}$ activities for this core from Griffins Bay (Fig. 1) exhibited a decreasing profile with increasing depth (Fig. 4, Table 3). The calculated CIC and CRS model sediment ages were in agreement (Table 3). ${ }^{137} \mathrm{Cs}$ activities were higher in the top $9 \mathrm{~cm}$ of the core (Table 3). Below $9 \mathrm{~cm}{ }^{137} \mathrm{Cs}$ activity dropped to $0.6 \mathrm{~Bq} \mathrm{~kg}{ }^{-1}$. According to the ${ }^{210} \mathrm{~Pb}$ chronology, the sediment layer at $6-9 \mathrm{~cm}$ was 46 years old, and the sediment at $9-12 \mathrm{~cm}$ was 65 years old. The low activity of ${ }^{137} \mathrm{Cs}$ detected below $9 \mathrm{~cm}$ may be a result of ${ }^{137} \mathrm{Cs}$ being mobile in the sediment core material. Otherwise the ${ }^{137} \mathrm{Cs}$ activities supported the ${ }^{210} \mathrm{~Pb}$ chronologies.

Based on ${ }^{210} \mathrm{~Pb}$ results, this core had a constant sedimentation rate of $0.2 \mathrm{~cm}_{\text {year }}{ }^{-1}$ and showed a decrease in metal concentrations from the deepest 1927 to 1945 year old sediment layer to the 6-9 cm layer, which corresponded to 1964-1982 (Fig. 4, Table 3). Metal concentrations then started to increase reaching a maximum at the 3-6 cm layer, which corresponded to $1982-$ 2001. With the exception of arsenic and cadmium, metal concentrations decreased in the top layer which corresponded to 2001-2010.

\subsubsection{Lake Illawarra core 8 replicate 2 (core 8.2)}

Unsupported ${ }^{210} \mathrm{~Pb}$ activities for this core from the central area of the lake (Fig. 1) exhibited a decreasing profile with increasing depth (Fig. 5, Table 3). The unsupported ${ }^{210} \mathrm{~Pb}$ activity at $12-15 \mathrm{~cm}$ was still relatively high (Table 3 ), thus more samples should be analysed below $15 \mathrm{~cm}$ until unsupported ${ }^{210} \mathrm{~Pb}$ reached close to the background level. For this reason the CIC model ${ }^{210} \mathrm{~Pb}$ dating ages were more accurate than the CRS model ages (Table 3). Significant levels of ${ }^{137} \mathrm{Cs}$ activity were detected in all the layers between 0 and $15 \mathrm{~cm}$ (Table 3), an indication that the sediment down to $15 \mathrm{~cm}$ had accumulated post the nuclear testing. At $12-15 \mathrm{~cm}$, the CIC sediment age was 40 years old, therefore the ${ }^{137} \mathrm{Cs}$ activities for this core support the CIC model ${ }^{210} \mathrm{~Pb}$ chronology.

Based on ${ }^{210} \mathrm{~Pb}$ results, this core had a constant sedimentation rate of $0.3 \mathrm{~cm}_{\text {year }}{ }^{-1}$ and showed a decrease in metal concentrations from the bottom $12-15 \mathrm{~cm}$ layer to the mid 9-12 cm, corresponding to 1978 to 1987 (Fig. 5). Metal concentrations then started to increase reaching a maximum at 6-9 cm, corresponding to 1987 to 1997 and slightly decreased again in the top sediment layer, with the exception of selenium which continued increasing and reached its maximum concentration at 3-6 cm corresponding to 1997 to 2006 , followed by a decrease in the top sediment layer.

\section{Discussion}

Our results showed that metal contamination has been occurring in this lake since the start of industrial activities in Port Kembla in the late 1800s (Figs. 4 and 5). Although contamination from Port Kembla started in the late 1800s, most metal contamination occurred from the 1960s.

Although the number of core replicates is low, the unsupported ${ }^{210} \mathrm{~Pb}$ had a steadily decreasing profile with increasing sediment depth, indicating that cores were not mixed and metal concentration profiles and sedimentation rates were well preserved. The general consistency in metal concentrations in core profiles between replicates (Fig. 2) indicated that core sediments were representative of the area they were sampled from, but caution should be taken when assessing site 1 , the location with highest metal concentrations, where there was disagreement between replicates (Fig. 2).

\subsection{Metal concentration variation with depth}

Metal concentrations in cores only reached background values within the sampled depth at sites 2, 3 and 4. Background metal concentrations in Lake Illawarra sediments were determined by Gillis and Birch (2006) and Ellis and Kanamori (1977) by calculating the mean concentration of metals in the fine fraction from the pre-anthropogenic section of sediment cores, which was assumed to be where the metal concentrations declined to a consistent minimum. Background metal concentrations in Lake Illawarra determined by their method were $\mathrm{Zn}<87 \mathrm{mg} \mathrm{kg}^{-1}, \mathrm{Cu}<39 \mathrm{mg} \mathrm{kg}^{-1}$, $\mathrm{Cd}<1 \mathrm{mg} \mathrm{kg}^{-1}$ and $\mathrm{Pb}<19 \mathrm{mg} \mathrm{kg}^{-1}$. Copper background values for Lake Illawarra were double than background concentrations in other estuaries in the region $\left(\approx 17 \mathrm{mg} \mathrm{kg}^{-1}\right)$. Background sediment copper concentrations may be the result of naturally high concentrations of copper in the Gerringong Volcanics, located in 


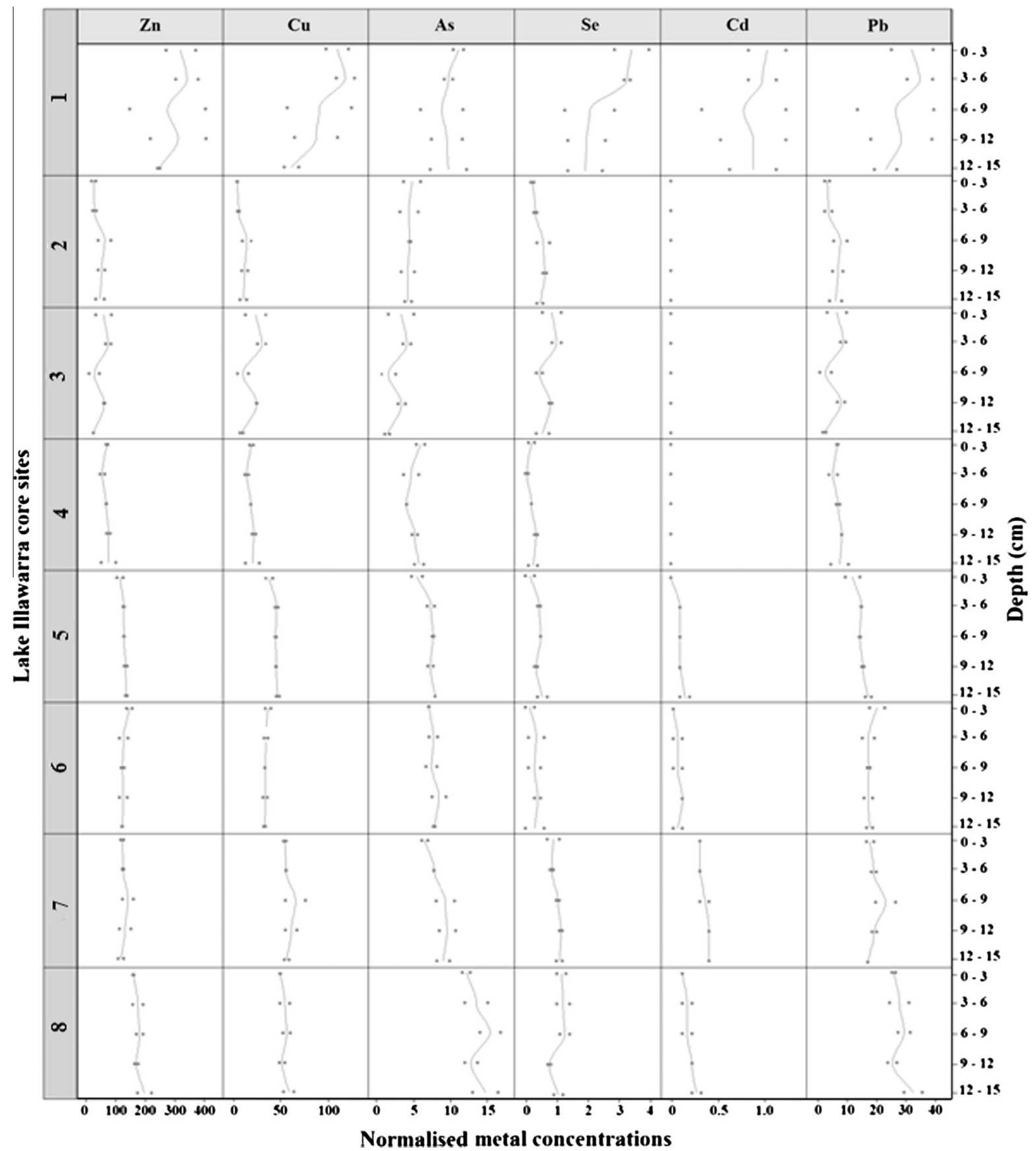

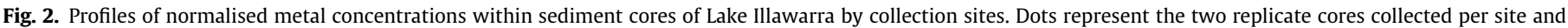
lines represent the average metal concentration between replicates. No lines indicate that metal concentrations are below detection limits.

the catchment (Carr, 1984; Zhou, 1985; Carballeira et al., 2000; Smith, 2001). Selenium concentrations did not reach background concentrations at sites 2,7 and 8 , and neither did arsenic concentrations at site 8 (Table 1 ).

No metal reached background concentration values at site 1 as a result of Port Kembla long-term industrial discharges which started in the beginning of the 1900s, in agreement with previous studies. The oldest study of metal concentration profiles in Lake Illawarra cores is by Ellis and Kanamori (1977), who collected samples in the 1970s. Their results agree with later results, and deposition during the subsequent 20 years shifted background values to about $5 \mathrm{~cm}$ deeper when Chenhall et al. (1994), Payne et al. (1997) and Gillis and Birch (2006) collected their cores. A different result, though, was obtained by Chenhall et al. (1994) who reported metal concentrations in two cores of $1 \mathrm{~m}$ depth. Their results showed that zinc, copper and lead background concentrations were found at about $60 \mathrm{~cm}$ depth. Depths at which maximum concentrations were found were different for each element, with the zinc maximum concentrations at around $10-15 \mathrm{~cm}$, copper maximum concentrations at around $50 \mathrm{~cm}$ while lead concentrations had different maxima in each core. One core, as for the other elements, had a lead concentration maximum at around $25 \mathrm{~cm}$, while, in the second core, an initial maximum at $88 \mathrm{~cm}$ was followed by another maximum at $25 \mathrm{~cm}$. This initial maximum was not recorded in previous published work probably because of limitations $(60 \mathrm{~cm})$ in core lengths. It is conceivable that the elevated lead concentrations 
Table 1

Whole sediment metal concentrations $\left(\mathrm{mg} \mathrm{kg}^{-1}\right.$ ) and normalised metal concentrations by depth of cores from sites 1 to 8 .

\begin{tabular}{|c|c|c|c|c|c|c|c|c|c|c|c|c|c|c|c|c|c|c|c|}
\hline \multicolumn{2}{|l|}{ Site } & \multicolumn{14}{|c|}{ Metals ( $\mathrm{mg} \mathrm{kg}^{-1}$ ) } & \multicolumn{4}{|c|}{ Grain size (\%) } \\
\hline Core & Depth (cm) & $\mathrm{Fe}$ & $\begin{array}{l}\text { Fe } \\
\text { Norm }\end{array}$ & $\mathrm{Zn}$ & $\begin{array}{l}\text { Zn } \\
\text { Norm }\end{array}$ & $\mathrm{Cu}$ & $\begin{array}{l}\mathrm{Cu} \\
\text { Norm }\end{array}$ & As & $\begin{array}{l}\text { As } \\
\text { Norm }\end{array}$ & $\mathrm{Se}$ & $\begin{array}{l}\text { Se } \\
\text { Norm }\end{array}$ & $\mathrm{Cd}$ & $\begin{array}{l}\text { Cd } \\
\text { Norm }\end{array}$ & $\mathrm{Pb}$ & $\begin{array}{l}\mathrm{Pb} \\
\text { Norm }\end{array}$ & $\begin{array}{l}\text { Clay } \\
<2 \mu \mathrm{m}\end{array}$ & $\begin{array}{l}\text { Silt } \\
2-20 \mu \mathrm{m}\end{array}$ & $\begin{array}{l}\text { Sand } \\
20-200 \mu \mathrm{m}\end{array}$ & $\begin{array}{l}\text { Coarse sand } \\
200-2000 \mu \mathrm{m}\end{array}$ \\
\hline \multirow[t]{5}{*}{1.1} & 0 & 9780 & 18500 & 284 & 154 & 101 & 54.5 & 11.4 & 6.2 & 2.8 & 1.5 & 0.9 & 0.5 & 28.4 & 15.4 & 14 & 29 & 41 & 17 \\
\hline & 3 & 11600 & 16800 & 317 & 189 & 111 & 66.0 & 10.1 & 6.0 & 3.1 & 1.8 & 0.9 & 0.5 & 33.9 & 20.2 & 12 & 24 & 55 & 10 \\
\hline & 6 & 6720 & 13200 & 162 & 123 & 60 & 45.6 & 6.9 & 5.2 & 1.2 & 0.9 & 0.4 & 0.3 & 17.0 & 12.9 & 6 & 13 & 59 & 22 \\
\hline & 9 & 7500 & 12900 & 232 & 179 & 67.5 & 52.3 & 8.4 & 6.5 & 1.3 & 1.0 & 0.6 & 0.5 & 21.4 & 16.6 & 7 & 11 & 44 & 38 \\
\hline & 12 & 7330 & 9740 & 264 & 271 & 56.5 & 58 & 8.2 & 8.4 & 1.3 & 1.3 & 0.7 & 0.7 & 22.8 & 23.4 & 1 & 3 & 35 & 61 \\
\hline \multirow[t]{5}{*}{1.2} & 0 & 14200 & 15900 & 385 & 243 & 124 & 78.1 & 12.8 & 8.1 & 3.9 & 2.5 & 1.3 & 0.8 & 42.6 & 26.9 & 0 & 31 & 56 & 13 \\
\hline & 3 & 14400 & 17500 & 394 & 225 & 130 & 74.1 & 11.3 & 6.4 & 3.3 & 1.9 & 1.2 & 0.7 & 42.4 & 24.2 & 1 & 38 & 55 & 6 \\
\hline & 6 & 15400 & 18100 & 417 & 231 & 127 & 70.3 & 12.7 & 7.0 & 2.8 & 1.5 & 1.3 & 0.7 & 42.8 & 23.7 & 1 & 40 & 53 & 6 \\
\hline & 9 & 14100 & 18000 & 419 & 233 & 113 & 62.6 & 12.6 & 7.0 & 2.5 & 1.4 & 1.3 & 0.7 & 42.3 & 23.5 & 1 & 40 & 53 & 6 \\
\hline & 12 & 12100 & 17400 & 256 & 147 & 72.2 & 41.5 & 13.2 & 7.6 & 2.4 & 1.4 & 1.2 & 0.7 & 30.3 & 17.4 & 1 & 37 & 53 & 9 \\
\hline \multirow[t]{5}{*}{2.1} & 0 & 4350 & 9490 & 26 & 27 & 4.0 & 4.2 & 7.0 & 7.4 & 0.2 & 0.2 & 0 & 0 & 5.3 & 5.6 & 0 & 3 & 5 & 92 \\
\hline & 3 & 5000 & 9540 & 28 & 29 & 6.3 & 6.6 & 6.6 & 6.9 & 0.2 & 0.2 & 0 & 0 & 6.0 & 6.3 & 0 & 3 & 12 & 85 \\
\hline & 6 & 5050 & 11300 & 35 & 31 & 9.0 & 8.0 & 5.4 & 4.8 & 0.3 & 0.3 & 0 & 0 & 6.6 & 5.9 & 1 & 10 & 15 & 75 \\
\hline & 9 & 7080 & 13700 & 58 & 42 & 14.7 & 10.7 & 6.1 & 4.4 & 0.6 & 0.4 & 0 & 0 & 9.8 & 7.1 & 1 & 20 & 23 & 55 \\
\hline & 12 & 6710 & 15300 & 55 & 36 & 13.7 & 9.0 & 5.7 & 3.7 & 0.3 & 0.2 & 0 & 0 & 9.4 & 6.2 & 2 & 27 & 21 & 51 \\
\hline 2.2 & 0 & 2890 & 9850 & 13 & 13 & 3.4 & 3.5 & 4.6 & 4.7 & 0.1 & 0.1 & 0 & 0 & 3.6 & 3.7 & 0 & 4 & 7 & 89 \\
\hline & 3 & 2970 & 9600 & 15 & 16 & 4.0 & 4.2 & 4.1 & 4.3 & 0.3 & 0.3 & 0 & 0 & 3.6 & 3.7 & 0 & 3 & 11 & 86 \\
\hline & 6 & 8120 & 16900 & 78 & 46 & 18.8 & 11.2 & 5.6 & 3.3 & 0.7 & 0.4 & 0 & 0 & 11.2 & 6.6 & 2 & 34 & 23 & 42 \\
\hline & 9 & 4880 & 12300 & 35 & 29 & 8.4 & 6.8 & 4.3 & 3.5 & 0.5 & 0.4 & 0 & 0 & 6.3 & 5.1 & 1 & 14 & 18 & 67 \\
\hline & 12 & 3780 & 13200 & 26 & 20 & 6.7 & 5.1 & 4.8 & 3.6 & 0.5 & 0.4 & 0 & 0 & 5.2 & 4.0 & 1 & 18 & 18 & 63 \\
\hline 3.1 & 0 & 2220 & 13450 & 32 & 24 & 12.7 & 9.4 & 2.3 & 1.7 & 0.4 & 0.3 & 0 & 0 & 4.2 & 3.1 & 0 & 20 & 21 & 58 \\
\hline & 3 & 5810 & 17600 & 83 & 47 & 34.7 & 19.7 & 5.4 & 3.1 & 1.0 & 0.6 & 0 & 0 & 10.6 & 6.0 & 1 & 38 & 40 & 21 \\
\hline & 6 & 737 & 11000 & 10 & 9 & 4.7 & 4.3 & 1.3 & 1.2 & 0.2 & 0.2 & 0 & 0 & 1.7 & 1.5 & 0 & 10 & 19 & 71 \\
\hline & 9 & 4090 & 15300 & 59 & 39 & 24.9 & 16.3 & 3.6 & 2.4 & 0.6 & 0.4 & 0 & 0 & 10.1 & 6.6 & 1 & 28 & 36 & 36 \\
\hline & 12 & 1980 & 12600 & 24 & 19 & 10.7 & 8.5 & 2.5 & 2 & 0.6 & 0.5 & 0 & 0 & 3.8 & 3.0 & 0 & 16 & 22 & 62 \\
\hline 3.2 & 0 & 5910 & 13900 & 86 & 62 & 34.6 & 24.9 & 5.8 & 4.2 & 1.0 & 0.7 & 0 & 0 & 10.8 & 7.8 & 0 & 22 & 29 & 49 \\
\hline & 3 & 4240 & 17300 & 65 & 38 & 25.9 & 15.0 & 4.3 & 2.5 & 0.7 & 0.4 & 0 & 0 & 8.8 & 5.1 & 1 & 37 & 40 & 22 \\
\hline & 6 & 2860 & 13400 & 45 & 34 & 16.2 & 12.1 & 3.3 & 2.5 & 0.4 & 0.3 & 0 & 0 & 5.6 & 4.2 & 0 & 20 & 27 & 53 \\
\hline & 9 & 4370 & 16700 & 62 & 37 & 24.7 & 14.8 & 4.6 & 2.8 & 0.7 & 0.4 & 0 & 0 & 7.7 & 4.6 & 1 & 34 & 38 & 27 \\
\hline & 12 & 1470 & 14300 & 24 & 17 & 7.3 & 5.1 & 1.8 & 1.3 & 0.2 & 0.1 & 0 & 0 & 2.8 & 1.9 & 0 & 24 & 30 & 46 \\
\hline 4.1 & 0 & 8170 & 17100 & 65 & 38 & 19.0 & 11.1 & 6 & 3.5 & 0.1 & 0.1 & 0 & 0 & 8.5 & 5.0 & 2 & 35 & 13 & 51 \\
\hline & 3 & 5450 & 18400 & 38 & 21 & 10.6 & 5.7 & 4.2 & 2.3 & 0.1 & 0.1 & 0 & 0 & 5.4 & 2.9 & 2 & 41 & 17 & 40 \\
\hline & 6 & 7260 & 21300 & 59 & 28 & 16.8 & 7.9 & 4.6 & 2.2 & 0.2 & 0.1 & 0 & 0 & 7.8 & 3.7 & 2 & 53 & 17 & 27 \\
\hline & 9 & 8610 & 18300 & 75 & 41 & 21.8 & 11.9 & 5.4 & 2.9 & 0.3 & 0.2 & 0 & 0 & 9.7 & 5.3 & 3 & 40 & 16 & 42 \\
\hline & 12 & 10500 & 16600 & 92 & 55 & 25.8 & 15.6 & 7.0 & 4.2 & 0.4 & 0.2 & 0 & 0 & 12.1 & 7.3 & 2 & 32 & 13 & 53 \\
\hline 4.2 & 0 & 7630 & 17100 & 58 & 34 & 15.7 & 9.2 & 7.1 & 4.1 & 0.3 & 0.2 & 0 & 0 & 8.1 & 4.7 & 2 & 35 & 15 & 48 \\
\hline & 3 & 7280 & 19300 & 54 & 28 & 14.4 & 7.5 & 6.3 & 3.3 & 0 & 0 & 0 & 0 & 8.3 & 4.3 & 3 & 44 & 12 & 41 \\
\hline & 6 & 7140 & 17500 & 60 & 34 & 16.8 & 9.6 & 4.6 & 2.6 & 0.2 & 0.1 & 0 & 0 & 9.2 & 5.2 & 3 & 36 & 15 & 47 \\
\hline & 9 & 7860 & 23800 & 61 & 25 & 17.9 & 7.5 & 6.1 & 2.6 & 0.4 & 0.2 & 0 & 0 & 9.8 & 4.1 & 4 & 63 & 14 & 19 \\
\hline & 12 & 6260 & 17300 & 44 & 25 & 11.2 & 6.5 & 5.7 & 3.3 & 0.1 & 0.1 & 0 & 0 & 6.0 & 3.5 & 2 & 35 & 11 & 51 \\
\hline 5.1 & 0 & 12400 & 18700 & 99 & 53 & 35.9 & 19.2 & 5.1 & 2.7 & 0.3 & 0.2 & 0 & 0 & 11.6 & 6.2 & 2 & 42 & 49 & 8 \\
\hline & 3 & 16300 & 19300 & 122 & 63 & 49.0 & 25.3 & 8.3 & 4.3 & 0.4 & 0.2 & 0.1 & 0.1 & 17.2 & 8.9 & 2 & 45 & 51 & 2 \\
\hline & 6 & 16300 & 20500 & 121 & 59 & 47.3 & 23.0 & 8.0 & 3.9 & 0.5 & 0.2 & 0.1 & 0 & 16.3 & 7.9 & 2 & 51 & 46 & 2 \\
\hline & 9 & 16400 & 21400 & 133 & 62 & 47.5 & 22.1 & 7.4 & 3.5 & 0.4 & 0.2 & 0.1 & 0 & 17.1 & 8.0 & 3 & 53 & 43 & 1 \\
\hline & 12 & 15800 & 22200 & 128 & 58 & 47.0 & 21.1 & 8.4 & 3.8 & 0.4 & 0.2 & 0.2 & 0.1 & 18.4 & 8.3 & 3 & 57 & 39 & 1 \\
\hline 5.2 & 0 & 14500 & 20100 & 118 & 59 & 43.4 & 21.6 & 6.6 & 3.3 & 0 & 0 & 0 & 0 & 16.5 & 8.2 & 2 & 49 & 48 & 2 \\
\hline & 3 & 15100 & 19600 & 119 & 61 & 45.8 & 23.3 & 7.3 & 3.7 & 0.5 & 0.3 & 0.1 & 0.1 & 16.9 & 8.6 & 2 & 46 & 50 & 2 \\
\hline & 6 & 15500 & 20400 & 123 & 61 & 46.2 & 22.7 & 8.2 & 4 & 0.5 & 0.2 & 0.1 & 0 & 16.8 & 8.2 & 2 & 49 & 47 & 2 \\
\hline & 9 & 15600 & 20700 & 122 & 59 & 46.8 & 22.7 & 8.1 & 3.9 & 0.3 & 0.1 & 0.1 & 0 & 18.0 & 8.7 & 3 & 50 & 43 & 4 \\
\hline & 12 & 16300 & 21200 & 132 & 63 & 50.1 & 23.7 & 8.4 & 4 & 0.7 & 0.3 & 0.1 & 0 & 20.4 & 9.6 & 3 & 52 & 43 & 2 \\
\hline 6.1 & 0 & 14400 & 24500 & 138 & 57 & 35.8 & 14.6 & 7.7 & 3.1 & 0 & 0 & 0 & 0 & 20.0 & 8.2 & 4 & 66 & 22 & 9 \\
\hline & 3 & 15200 & 23300 & 143 & 61 & 38.8 & 16.7 & 9.0 & 3.9 & 0.1 & 0 & 0 & 0 & 21.6 & 9.3 & 5 & 59 & 25 & 11 \\
\hline & 6 & 14000 & 23900 & 131 & 55 & 35.3 & 14.8 & 7.4 & 3.1 & 0.1 & 0 & 0 & 0 & 19.3 & 8.1 & 6 & 61 & 27 & 7 \\
\hline & 9 & 14600 & 23900 & 141 & 59 & 38.6 & 16.2 & 10.1 & 4.2 & 0.3 & 0.1 & 0.1 & 0 & 21.0 & 8.8 & 4 & 63 & 24 & 9 \\
\hline & 12 & 13600 & 23500 & 123 & 52 & 34.0 & 14.4 & 8.4 & 3.6 & 0 & 0 & 0 & 0 & 19.0 & 8.1 & 5 & 61 & 24 & 10 \\
\hline 6.2 & 0 & 16200 & 27500 & 157 & 57 & 41.9 & 15.2 & 7.8 & 2.8 & 0.3 & 0.1 & 0 & 0 & 25.1 & 9.1 & 3 & 80 & 17 & 1 \\
\hline & 3 & 14700 & 23500 & 114 & 49 & 34.8 & 14.8 & 7.8 & 3.3 & 0.6 & 0.3 & 0.1 & 0 & 17.6 & 7.5 & 4 & 61 & 26 & 10 \\
\hline & 6 & 15600 & 23500 & 120 & 51 & 35.8 & 15.3 & 8.9 & 3.8 & 0.5 & 0.2 & 0.1 & 0 & 20.2 & 8.6 & 5 & 60 & 25 & 10 \\
\hline & 9 & 14300 & 23700 & 114 & 48 & 33.1 & 14.0 & 8.2 & 3.5 & 0.5 & 0.2 & 0.1 & 0 & 18.2 & 7.7 & 4 & 62 & 24 & 11 \\
\hline & 12 & 15600 & 23200 & 125 & 54 & 36.2 & 15.6 & 8.6 & 3.7 & 0.6 & 0.3 & 0.1 & 0 & 21.1 & 9.1 & 5 & 59 & 25 & 11 \\
\hline 7.1 & 0 & 14300 & 21600 & 110 & 51 & 52.4 & 24.3 & 6.8 & 3.1 & 1.2 & 0.6 & 0.3 & 0.1 & 18.0 & 8.3 & 2 & 55 & 42 & 2 \\
\hline & 3 & 15400 & 22200 & 117 & 53 & 54.9 & 24.8 & 8.5 & 3.8 & 1.0 & 0.5 & 0.3 & 0.1 & 19.6 & 8.8 & 3 & 57 & 40 & 0 \\
\hline & 6 & 21600 & 22800 & 154 & 68 & 75.3 & 33.0 & 11.4 & 5.0 & 1.2 & 0.5 & 0.4 & 0.2 & 27.9 & 12.2 & 3 & 60 & 37 & 1 \\
\hline & 9 & 16200 & 22200 & 106 & 48 & 54.1 & 24.4 & 9.2 & 4.1 & 1.2 & 0.5 & 0.4 & 0.2 & 19.8 & 8.9 & 3 & 56 & 40 & 1 \\
\hline & 12 & 15400 & 22200 & 103 & 46 & 52.6 & 23.7 & 8.9 & 4.0 & 1.3 & 0.6 & 0.4 & 0.2 & 18.3 & 8.2 & 3 & 57 & 35 & 5 \\
\hline
\end{tabular}


Table 1 (continued)

\begin{tabular}{|c|c|c|c|c|c|c|c|c|c|c|c|c|c|c|c|c|c|c|c|}
\hline \multicolumn{2}{|l|}{ Location } & \multicolumn{14}{|c|}{ Metals $\left(\mathrm{mg} \mathrm{kg}^{-1}\right)$} & \multicolumn{4}{|c|}{ Grain size (\%) } \\
\hline Site core & Depth (cm) & $\mathrm{Fe}$ & $\begin{array}{l}\text { Fe } \\
\text { Norm }\end{array}$ & $\mathrm{Zn}$ & $\begin{array}{l}\text { Zn } \\
\text { Norm }\end{array}$ & $\mathrm{Cu}$ & $\begin{array}{l}\mathrm{Cu} \\
\text { Norm }\end{array}$ & As & $\begin{array}{l}\text { As } \\
\text { Norm }\end{array}$ & $\mathrm{Se}$ & $\begin{array}{l}\text { Se } \\
\text { Norm }\end{array}$ & $\mathrm{Cd}$ & $\begin{array}{l}\text { Cd } \\
\text { Norm }\end{array}$ & $\mathrm{Pb}$ & $\begin{array}{l}\mathrm{Pb} \\
\text { Norm }\end{array}$ & $\begin{array}{l}\text { Clay } \\
<2 \mu \mathrm{m}\end{array}$ & $\begin{array}{l}\text { Silt } \\
2-20 \mu \mathrm{m}\end{array}$ & $\begin{array}{l}\text { Sand } \\
20-200 \mu \mathrm{m}\end{array}$ & $\begin{array}{l}\text { Coarse sand } \\
200-2000 \mu \mathrm{m}\end{array}$ \\
\hline \multirow[t]{5}{*}{7.2} & 0 & 15400 & 22800 & 121 & 53 & 55.0 & 24.1 & 7.6 & 3.3 & 0.8 & 0.4 & 0.3 & 0.1 & 20.4 & 8.9 & 2 & 61 & 38 & 1 \\
\hline & 3 & 16100 & 21400 & 121 & 57 & 55.0 & 25.6 & 8.5 & 4.0 & 0.9 & 0.4 & 0.3 & 0.1 & 21.2 & 9.9 & 4 & 52 & 43 & 1 \\
\hline & 6 & 15900 & 22900 & 117 & 51 & 54.4 & 23.7 & 8.8 & 3.8 & 1.1 & 0.5 & 0.3 & 0.1 & 21.0 & 9.2 & 3 & 60 & 37 & 1 \\
\hline & 9 & 20500 & 22800 & 145 & 64 & 66.5 & 29.1 & 11.5 & 5.0 & 1.3 & 0.6 & 0.4 & 0.2 & 21.4 & 9.4 & 3 & 59 & 37 & 0 \\
\hline & 12 & 18900 & 23000 & 120 & 52 & 57.9 & 25.1 & 10.7 & 4.6 & 1.1 & 0.5 & 0.4 & 0.2 & 18.4 & 8.0 & 3 & 60 & 36 & 1 \\
\hline \multirow[t]{5}{*}{8.1} & 0 & 20700 & 27200 & 166 & 61 & 48.0 & 17.7 & 13.8 & 5.1 & 1.3 & 0.5 & 0.1 & 0 & 28.0 & 10.3 & 3 & 79 & 17 & 2 \\
\hline & 3 & 21000 & 27100 & 166 & 61 & 47.4 & 17.5 & 13.0 & 4.8 & 1.0 & 0.4 & 0.1 & 0 & 26.1 & 9.6 & 4 & 77 & 17 & 2 \\
\hline & 6 & 22200 & 27500 & 177 & 64 & 50.6 & 18.4 & 15.1 & 5.5 & 1.4 & 0.5 & 0.1 & 0 & 28.9 & 10.5 & 5 & 78 & 15 & 2 \\
\hline & 9 & 21100 & 27800 & 185 & 67 & 52.1 & 18.8 & 14.8 & 5.3 & 0.8 & 0.3 & 0.2 & 0.1 & 28.4 & 10.2 & 5 & 79 & 15 & 1 \\
\hline & 12 & 20500 & 27600 & 182 & 66 & 51.1 & 18.5 & 14.1 & 5.1 & 1.2 & 0.4 & 0.2 & 0.1 & 30.9 & 11.2 & 5 & 79 & 16 & 1 \\
\hline \multirow[t]{5}{*}{8.2} & 0 & 20500 & 28600 & 170 & 60 & 47.4 & 16.6 & 12.7 & 4.4 & 1.0 & 0.3 & 0.1 & 0 & 26.9 & 9.4 & 15 & 73 & 12 & 0 \\
\hline & 3 & 24100 & 28900 & 200 & 69 & 57.6 & 19.9 & 16.2 & 5.6 & 1.4 & 0.5 & 0.2 & 0.1 & 32.7 & 11.3 & 15 & 74 & 11 & 0 \\
\hline & 6 & 24100 & 26900 & 200 & 74 & 57.8 & 21.5 & 17.9 & 6.7 & 1.1 & 0.4 & 0.2 & 0.1 & 33.1 & 12.3 & 14 & 67 & 17 & 3 \\
\hline & 9 & 19300 & 27400 & 172 & 63 & 46.5 & 17.0 & 13.0 & 4.7 & 0.7 & 0.3 & 0.2 & 0.1 & 25.5 & 9.3 & 15 & 68 & 11 & 6 \\
\hline & 12 & 26100 & 28500 & 229 & 80 & 61.8 & 21.7 & 17.6 & 6.2 & 0.9 & 0.3 & 0.3 & 0.1 & 37.2 & 13 & 15 & 73 & 12 & 1 \\
\hline
\end{tabular}

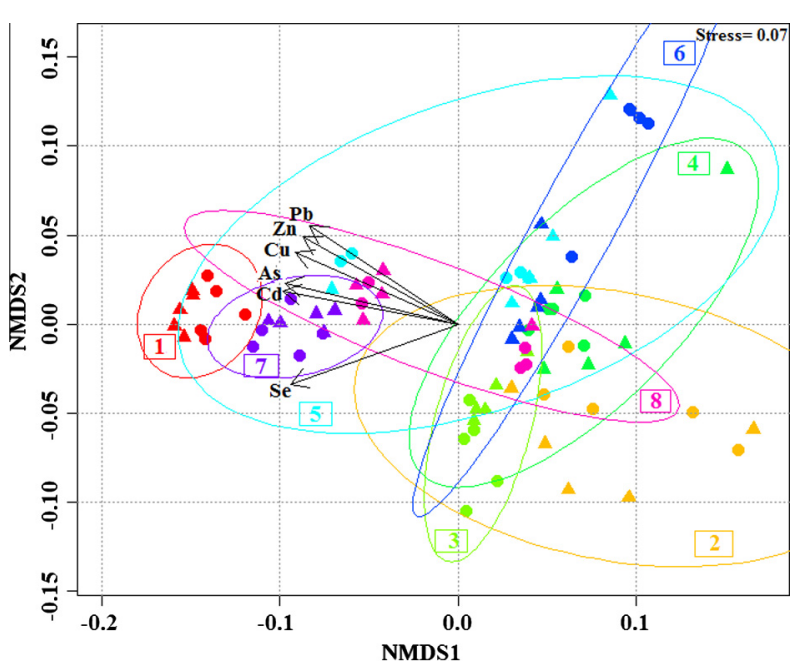

Fig. 3. MDS plot showing between-site similarity in metal concentrations in sediments from Lake Illawarra. Plot based on data for eight original cores (circles) and eight replicates (triangles), with points colour coded for sites. Arrows represent the relative contribution of the original variables to the variability along the first two MDSs. (For interpretation of the references to colour in this figure legend, the reader is referred to the web version of this article.)

Table 2

Pairwise comparisons of metal dissimilarity ranks between cores from Lake Illawarra.

\begin{tabular}{|c|c|c|c|c|c|c|c|c|}
\hline Sites & Between & 1 & 2 & 3 & 4 & 5 & 6 & 7 \\
\hline 1 & * & - & - & - & - & - & - & - \\
\hline 2 & $* * *$ & $* * *$ & - & - & - & - & - & - \\
\hline 3 & 0.0023 & $* * *$ & 1 & - & - & - & - & - \\
\hline 4 & ${ }^{* * * *}$ & $* * *$ & 1 & 0.4 & - & - & - & - \\
\hline 5 & $* * *$ & $* * *$ & ** & $* * *$ & 0.1 & - & - & - \\
\hline 6 & $* * *$ & $* * *$ & * & $* * *$ & 0.4 & 1 & - & - \\
\hline 7 & $* * *$ & $* * *$ & 1 & $* *$ & 1 & 1 & 1 & - \\
\hline 8 & *** & $* * *$ & 1 & **** & 1 & 1 & 1 & 1 \\
\hline
\end{tabular}

in the deeper cores reflect the inputs of the first industrial activities (lead smelting in 1896). An alternative hypothesis, involving mobilisation of lead down the sediment column, does not appear to be feasible, given the sharply defined nature of lead enrichment, unless, a change in physicochemical factors resulted in lead fixation at specific depths.

\subsection{Metal concentrations between sites}

Site 1 at Griffins Bay (Fig. 1) showed the most enrichment in metal concentrations within cores (Fig. 2). This was the site that best reflected historical industrial activities as metal concentration changes in cores (Figs. 2 and 3). The high concentrations of metals in sediments at this site next to Port Kembla confirm that this industrial complex is an important source of metals, which is in agreement with previous studies (Roy and Peat, 1976; Ellis and Kanamori, 1977; Chenhall et al., 1994; Payne et al., 1997; Chiaradia et al., 1997; Gillis and Birch, 2006). An explanation for this discharge of metals has been given by Gillis and Birch (2006) who reported that sediment in Minnegang and Wegit Creeks discharging into Griffins Bay contained higher metal concentrations than sediments mantling Griffins Bay, suggesting that these creeks are the source of metals to the embayment. These creeks drain sub-catchments associated with urban areas adjacent to Port Kembla. Beavington (1973) reported elevated concentrations of acetic acid-extractable zinc $\left(103 \mathrm{mg} \mathrm{kg}^{-1}\right)$, lead (17 $\left.\mathrm{mg} \mathrm{kg}^{-1}\right)$, cadmium (1.0 $\mathrm{mg} \mathrm{kg}^{-1}$ ), and EDTA-extractable copper (488 $\mathrm{mg} \mathrm{kg}^{-1}$ ), in soils from urban areas adjacent to Port Kembla, suggesting that top soil erosion may be a source of metals to the creeks. Water exchange between Griffins Bay and the main body of the lake is usually limited by a sub-aqueous spit (Clarke and Eliot, 1984) thus Griffins Bay acts as a sink for sediments and associated metals entering the embayment.

Site 8 at the Windang Peninsula, where copper slag containing zinc, copper, lead and cadmium was dumped, had slightly elevated concentrations of arsenic and lead relative to sites $2-7$, but no evidence of copper and cadmium enrichment.

Distinctively higher metal concentrations at site 1 in Griffins Bay sediments compared with the rest of Lake Illawarra, suggest that direct atmospheric deposition of metals is not the main mechanism governing metal distribution in the lake. Had atmospheric contributions been the dominant source of metals to the lake, metal concentrations would show a uniform gradient across the northern part of the lake, which was not evident from the data collected in the current work. Inputs from creeks in the northeast, as reported by Gillis and Birch (2006), appear to be more important in determining spatial metal concentration patterns than atmospheric processes.

\subsection{Sedimentation rates}

The sedimentation rates give an indication of lake dynamics and sediment movement (Tylmann, 2004). In Lake Illawarra, 


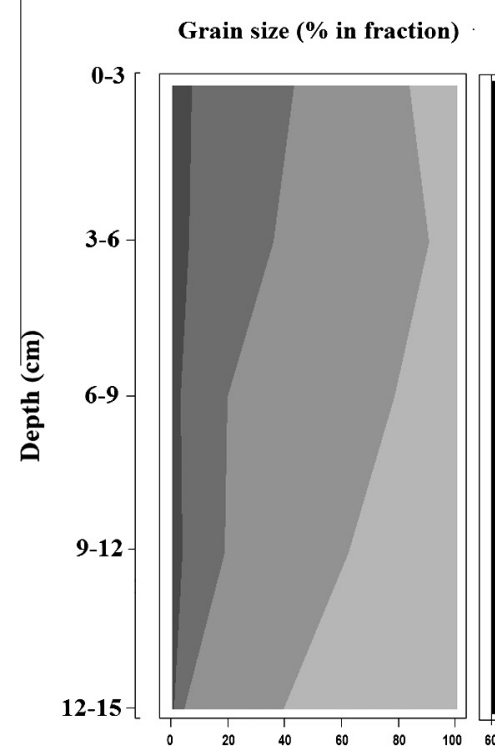

b

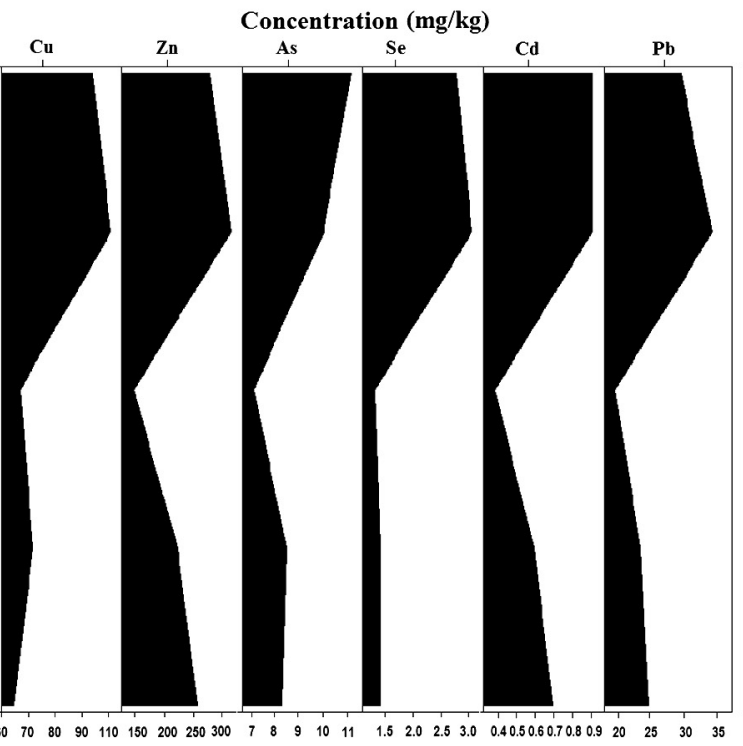

c

Unsupported ${ }^{210} \mathrm{~Pb}$ $(\mathrm{Bq} / \mathrm{kg})$

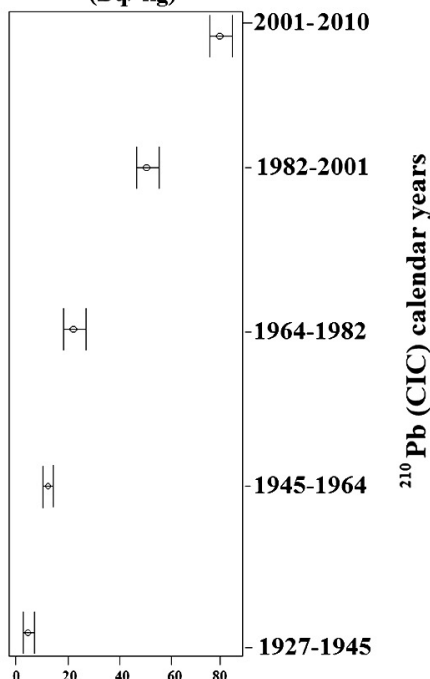

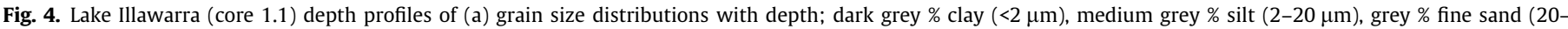
$200 \mu \mathrm{m})$, light grey $\%$ coarse sand $(200-2000 \mu \mathrm{m})$, (b) total metal concentration and (c) ${ }^{210} \mathrm{~Pb}$ activity depth profile.

Table 3

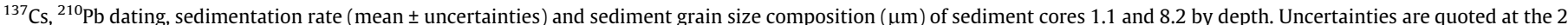
sigma level.

\begin{tabular}{|c|c|c|c|c|c|c|c|c|c|c|c|c|}
\hline Site core & Depth $(\mathrm{cm})$ & $\begin{array}{l}\text { Total }{ }^{210} \mathrm{~Pb} \\
\left(\mathrm{~Bq} \mathrm{~kg}^{-1}\right)\end{array}$ & $\begin{array}{l}\text { Supported } \\
{ }^{210} \mathrm{~Pb}\left(\mathrm{~Bq} \mathrm{~kg}^{-1}\right)\end{array}$ & $\begin{array}{l}\text { Unsupported } \\
{ }^{210} \mathrm{~Pb}\left(\mathrm{~Bq} \mathrm{~kg}^{-1}\right)\end{array}$ & $\begin{array}{l}{ }^{137} \mathrm{Cs} \\
\left(\mathrm{Bq} \mathrm{kg}^{-1}\right)\end{array}$ & $\begin{array}{l}\text { CIC age } \\
\text { (year) }\end{array}$ & $\begin{array}{l}\text { CRS age } \\
\text { (year) }\end{array}$ & $\begin{array}{l}\text { Sedimentation } \\
\left(\mathrm{cm}_{\text {year }}^{-1}\right)\end{array}$ & $\begin{array}{l}\text { \% Clay } \\
<2 \mu \mathrm{m}\end{array}$ & $\begin{array}{l}\text { \% Silt } \\
2-20 \mu \mathrm{m}\end{array}$ & $\begin{array}{l}\text { \% Sand } \\
20-200 \mu \mathrm{m}\end{array}$ & $\begin{array}{l}\text { \% Coarse sand } \\
200-2000 \mu \mathrm{m}\end{array}$ \\
\hline \multirow[t]{5}{*}{1.1} & $0-3$ & 96 & $11 \pm 1.8$ & $85 \pm 5.7$ & $2.1 \pm 0.4$ & $9 \pm 9$ & $9 \pm 3$ & $0.2 \pm 0.01$ & 7 & 36 & 41 & 17 \\
\hline & $3-6$ & 65 & $11 \pm 1.4$ & $54 \pm 3.6$ & $2.2 \pm 0.3$ & $28 \pm 9$ & $27 \pm 5$ & $0.2 \pm 0.01$ & 6 & 30 & 55 & 10 \\
\hline & $6-9$ & 35 & $9 \pm 1.2$ & $26 \pm 3.2$ & $1.1 \pm 0.2$ & $46 \pm 9$ & $46 \pm 7$ & $0.2 \pm 0.02$ & 2.8 & 17 & 59 & 22 \\
\hline & $9-12$ & 23 & $7 \pm 1.6$ & $17 \pm 1.9$ & $0.6 \pm 0.4$ & $65 \pm 10$ & $64 \pm 8$ & $0.2 \pm 0.03$ & 3.5 & 15 & 44 & 38 \\
\hline & $12-15$ & 15 & $6 \pm 1.4$ & $9 \pm 2.3$ & $0.6 \pm 0.2$ & $83 \pm 10$ & $82 \pm 9$ & $0.2 \pm 0.04$ & 0.6 & 4 & 35 & 61 \\
\hline \multirow[t]{5}{*}{8.2} & $0-3$ & 70 & $14 \pm 1.8$ & $56 \pm 5.3$ & $2.9 \pm 0.4$ & $4 \pm 4$ & $7 \pm 2$ & $0.4 \pm 0.04$ & 15 & 73 & 12 & 0 \\
\hline & $3-6$ & 64 & $16 \pm 1.5$ & $48 \pm 5.3$ & $2.7 \pm 0.4$ & $13 \pm 5$ & $11 \pm 4$ & $0.3 \pm 0.03$ & 15 & 74 & 11 & 0.2 \\
\hline & $6-9$ & 51 & $16 \pm 1.5$ & $35 \pm 3.5$ & $3.3 \pm 0.3$ & $23 \pm 5$ & $19 \pm 5$ & $0.3 \pm 0.03$ & 14 & 67 & 17 & 3.2 \\
\hline & $9-12$ & 38 & $16 \pm 1.5$ & $22 \pm 5.2$ & $2.6 \pm 0.5$ & $32 \pm 6$ & $25 \pm 7$ & $0.4 \pm 0.07$ & 15 & 68 & 11 & 6.3 \\
\hline & $12-15$ & 36 & $20 \pm 1.4$ & $16 \pm 4.3$ & $3.7 \pm 0.4$ & $41 \pm 6.4$ & $41 \pm 6$ & $0.3 \pm 0.02$ & 15 & 73 & 12 & 0.5 \\
\hline
\end{tabular}

sedimentation rates of 0.2 and $0.3 \mathrm{~cm}_{\text {year }}{ }^{-1}$ were found in site 1 (Griffins Bay) and site 8 (centre of the lake) respectively. The sedimentation rate found for site 1 is similar to that previously reported (Chenhall et al., 1994; Payne et al., 1997), but not for site 8 which had a rate reported as $0.9 \mathrm{~cm}$ year $^{-1}$ (Chenhall et al., 1994). This discrepancy can be explained by the different methodologies used. While this study uses ${ }^{210} \mathrm{~Pb},{ }^{137} \mathrm{Cs}$ and metal profiles, Chenhall et al. (1994) only used sediment ash and metal profiles. There was a discrepancy between ash and metal concentration profiles in his study, with ash profiles resulting in a higher sedimentation rate.

Based on the results of this study, therefore, it is feasible to conclude that the sedimentation rate in Lake Illawarra from the 1930s have been constant at sites 1 and 8 , indicating that human activity has not changed the sedimentation rate during this period.

\subsection{History of anthropogenic metal contamination}

The distributions of copper, zinc, arsenic, selenium, cadmium and lead concentrations within core 1.1 (Fig. 4) were in agreement with historical events in the southern part of the lake contributing to the inputs of metals. Contamination in the lake started below core layers, which corresponds to the commencement of industrial activities in Port Kembla at around 1910-1920 and intensified in 1947, with the creation of a Greater City of Wollongong.

Core 8.2, however, showed a different metal concentration profile in sediments which does not match the history of contamination from Port Kembla industry or Tallawarra Power Station. The bottom layer of the core, which according to ${ }^{210} \mathrm{~Pb}$ corresponds to the 1970s, should present an increase in metal concentrations, but a decrease of metal concentrations was found corresponding to the start of the power station. The decrease in metal concentrations expected in 1989 was only slight in core 8.2, with the greatest decrease in metal concentrations actually seen at the top of the core, corresponding to the years of 2006-2010. These results were not expected and make it difficult to propose a sensible explanation of historical changes in metal concentrations at this location. Even considering that sedimentation rates and dates may have been underestimated for this core and considering a sedimentation rate of $0.9 \mathrm{~cm}$ year ${ }^{-1}$ as reported by Chenhall et al. (1994), changes in metal concentration profiles do not agree with historical inputs from Tallawarra Power Station or the Port Kembla Industrial Complex. The most plausible explanation for the anomaly in this core is that contamination is a result of the water flow movement spreading contaminants from Tallawarra Power Station, preventing them 
a

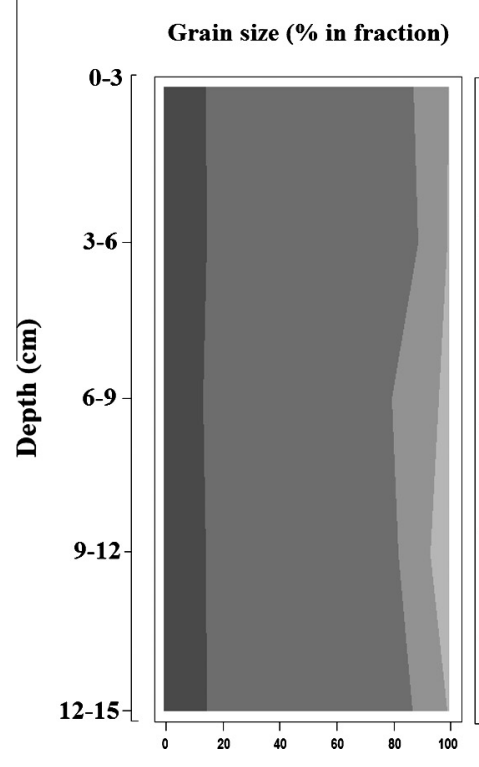

b

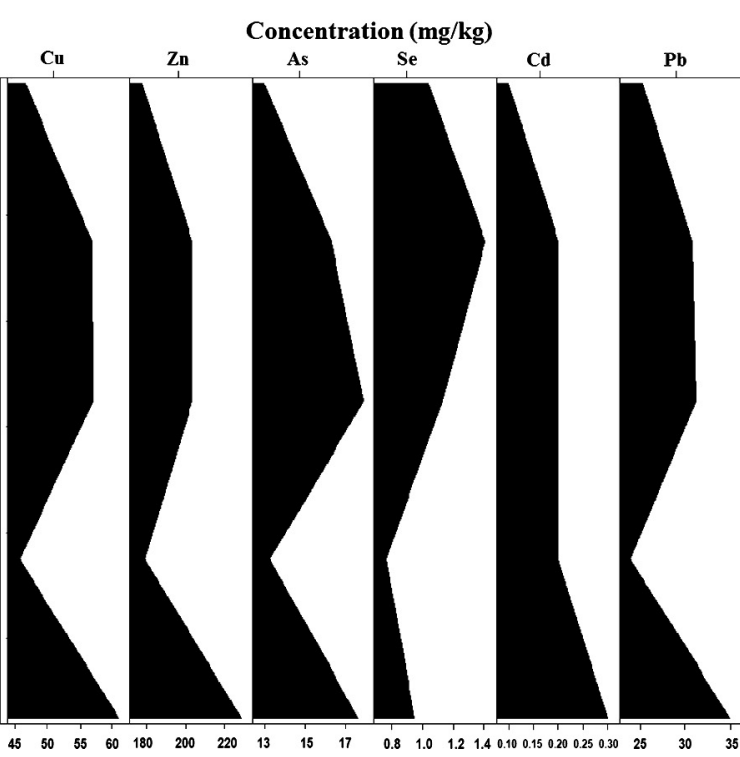

c

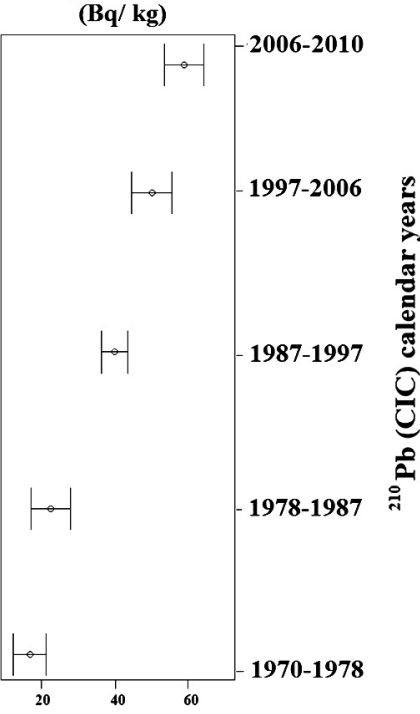

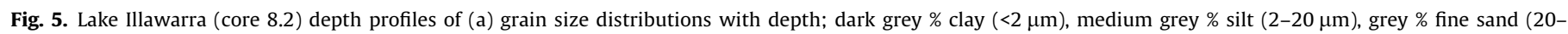
$200 \mu \mathrm{m})$, light grey $\%$ coarse sand $(200-2000 \mu \mathrm{m})$, (b) total metal concentration and $(\mathrm{c}){ }^{210} \mathrm{~Pb}$ activity depth profile.

being concentrated in one spot (DECCW, 2009). In addition, the main source of metals according to history is the Windang Peninsula, an area located between the Pacific Ocean and the Lake. This region has been the subject of significant sand extraction activities, while granulated copper slag from a copper-smelter refinery in Port Kembla was dumped into the ground. Yassini (2004) reported this copper slag as consisting of aluminium, magnesium, zinc, copper, lead and cadmium. Although selenium concentrations were not reported by Yassini (2004), it is known to be produced from copper refinery slimes and from flue dusts from copper smelters (Hoffmann, 1989; Green, 2006). Examination of early aerial photography suggested that these activities may have begun as early as 1945 (Yassini, 2004), which agrees with the high concentration of metals in the base of the core corresponding to the period of 1970-1978.

\subsection{Sediment metal concentrations and sediment quality guidelines}

In Australia, the Australian and New Zealand Guidelines for Fresh and Marine Water Quality (ANZECC/ARMCANZ, 2000) outline the criteria for assessing site contamination and determining the requirements for further investigation, or assessment of risk to determine if any further action is required. This document advises further investigation if sediment metal concentrations are above the low trigger values of: $\mathrm{Cd} 1.5 \mathrm{mg} \mathrm{kg}^{-1}, \mathrm{Cu} 65 \mathrm{mg} \mathrm{kg}^{-1}, \mathrm{~Pb}$ $50 \mathrm{mg} \mathrm{kg}^{-1}$, Zn $500 \mathrm{mg} \mathrm{kg}^{-1}$. There was no guideline established for selenium in Australia as a result of limited data availability.

In Lake Illawarra, the metal of highest concern is zinc, which was higher than the sediment quality guideline value at sites 1 and 8, and copper at sites 1 and 7, most likely as a result of Port Kembla industries rather than the activities of the Tallawarra Power Station.

\section{Conclusions}

Our results contribute to a body of evidence that Lake Illawarra has faced a history of metal contamination, manifested by their accumulation in deposited sediments. Metal concentrations peaked in the 1960s around the time that the Tallawarra Power
Station commenced operation, although elevated metal concentrations were present in the 1930s by which time a steelworks and copper smelter were in operation at Port Kembla. Our results for selenium and arsenic suggest that the coal-fired power station was not their main source to the Lake but the origin was Port Kembla. The metals of highest concern were zinc and copper, which exceeded the Australian sediment quality guideline values at sites 1 and 8 for zinc and sites 1 and 7 for copper.

\section{Acknowledgements}

We thank Aaron Wright and Cheyne Ramsay of the NSW Office of Environment and Heritage for providing substantial field and logistical support, and the Australian Institute of Nuclear Science and Engineering (AINSE) for providing funds and access to the national facilities at ANSTO to conduct dating analysis. We also thank Iradj Yassini and the Wollongong City Council for providing and discussing information for this paper. Larissa Schneider was financed by an International Postgraduate Research Scholarship (IPRS) funded by the Australian Government.

\section{Appendix A. Supplementary material}

Supplementary data associated with this article can be found, in the online version, at http://dx.doi.org/10.1016/j.chemosphere. 2014.06.058.

\section{References}

Andutta, F.P., Wang, X.H., Li, L., Williams, D., 2013. Hydrodynamics and sediment transport in a macro-tidal estuary: Darwin Harbour, Australia. In: Wolanski, E. (Ed.), Estuaries of Australia in 2050 and Beyond. Springer, Netherlands, pp. 111129.

ANZECC/ARMCANZ, 2000. Australian and New Zealand Guidelines for Fresh and Marine Water Quality. Australian and New Zealand Environment and Conservation Council/Agriculture and Resource Management Council of Australia and New Zealand, Canberra, ACT (Australia).

Appleby, P.G., Oldfield, F., 1992. Application of 210-Pb to sedimentation studies. In: Ivanovich, M., Harmon, R.S. (Eds.), Uranium-Series Disequilibrium. Applications to Earth, Marine and Environmental Sciences. Oxford Science, Oxford (UK), pp. 731-778. 
Batley, G.E., 1987. Heavy metal speciation in waters, sediments and biota from Lake Macquarie, New South Wales. Mar. Freshw. Res. 38, 591-606.

Beavington, F., 1973. Contamination of soil with zinc, copper, lead, and cadmium in the Wollongong city area. Soil Res. 11, 27-31.

Blomqvist, S., Larsson, U., Borg, H., 1992. Heavy metal decrease in the sediments of a Baltic bay following tertiary sewage treatment. Mar. Pollut. Bull. 24, 258-266.

Carballeira, A., Carral, E., Puente, X., Villares, R., 2000. Regional-scale monitoring of coastal contamination. Nutrients and heavy metals in estuarine sediments and organisms on the coast of Galicia (northwest Spain). Int. J. Environ. Pollut. 13, 534-572.

Carlile, P.W., Bui, E.N., Moran, C.J., et al., 2001. Method used to Generate Soil Attribute Surfaces for the Australian Soil Resource Information System using Soil Maps and Look-Up Tables. CSIRO Land and Water, Canberra (Australia).

Carr, P., 1984. The Late Permian Shoshonitic Province of the Southern Sydney Basin. University of Wollongong.

Chenhall, B.E., Batley, G.E., Yassini, I., et al., 1994. Ash distribution and metal contents of Lake Illawarra bottom sediments. Mar. Freshw. Res. 45, 977-992.

Chenhall, B.E., Yassini, I., Depers, A.M., et al., 1995. Anthropogenic marker evidence for accelerated sedimentation in Lake Illawarra, New South Wales, Australia. Environ. Geol. 26, 124-135.

Chenhall, B.E., Jones, B.G., Sloss, C.R., et al., 2004. Trace metals in sediments from Lake Illawarra, New South Wales, Australia. Wetlands (Australia) 217, 198-208.

Chiaradia, M., Chenhall, B.E., Depers, A.M., et al., 1997. Identification of historical lead sources in roof dusts and recent lake sediments from an industrialized area: indications from lead isotopes. Sci. Total Environ. 205, 107-128.

Clarke, K.R., 1993. Non-parametric multivariate analyses of changes in community structure. Aust. J. Ecol. 18, 117-143.

Clarke, D.J., Eliot, I.G., 1984. Wind Driven Water Circulation in Lake Illawarra, New South Wales: A Numerical Simulation. University of Wollongong.

Dale, L., 2006. Trace Elements in Coal, Australian Coal Association Research Program. In: ACARP Report No. 2, p. 8.

Deaker, M., Maher, W., 1995. Determination of selenium in seleno compounds and marine biological tissues using electrothermal atomization atomic absorption spectrometry. J. Anal. At. Spectrom. 10, 423-431.

DECCW, 2009. Lake Illawarra Tidal Data Collection. Department of Environment, Climate Change and Water, NSW (Australia).

Eklund, E.C., 2002. Steel Town: the Making and Breaking of Port Kembla. Melbourne University Press, Melbourne (Australia). p. 230.

Ellis, J., Kanamori, S., 1977. Water pollution studies on Lake Illawarra. III. Distribution of heavy metals in sediments. Mar. Freshw. Res. 28, 485-496.

Energy Australia, 2013. Tallawarra Power Station - Generation and Assets - Energy Australia. <http://www.energyaustralia.com.au/tallawarra>. (Accessed 6.09.2013.

Gillis, A.C., Birch, G.F. 2006. Investigation of anthropogenic trace metals in sediments of Lake Illawarra, New South Wales. Aust. J. Earth Sci. 53, 523-539.

Green, M.A., 2006. Improved estimates for Te and Se availability from Cu anode slimes and recent price trends. Prog. Photovoltaics Res. Appl. 14, 743-751.

Hanson, P.J., Evans, D.W., Colby, D.R., Zdanowicz, V.S., 1993. Assessment of elemental contamination in estuarine and coastal environments based on geochemical and statistical modeling of sediments. Mar. Environ. Res. 36, 237266.

Harvey, N., Caton, B., 2010. Coastal Management in Australia. The University of Adelaide Press, Adelaide (Australia).

Hoffmann, J.E., 1989. Recovering selenium and tellurium from copper refinery slimes. JOM 41, 33-38.

Hollins, S.E., Harrison, J.J., Jones, B.G., et al., 2011. Reconstructing recent sedimentation in two urbanised coastal lagoons (NSW, Australia) using radioisotopes and geochemistry. J. Paleolimnol. 46, 579-596.

Kilby, G.W., Batley, G.E., 1993. Chemical indicators of sediment chronology. Mar. Freshw. Res. 44, 635-647.

Krantzberg, G., 1985. The influence of bioturbation on physical, chemical and biological parameters in aquatic environments: a review. Environ. Pollut. 39, 99-122.

Legendre, P., Legendre, L., 2012. Numerical Ecology. Elsevier, Amsterdam (Netherlands).

Maher, W., Forster, S., Krikowa, F., et al., 2001. Measurement of trace elements and phosphorus in marine animal and plant tissues by low-volume microwave digestion and ICP-MS. At. Spectrosc. 22, 361-370.

McKenzie, N.J., Jacquier, D.W., Ashton, L.J., Cresswell, H.P., 2000. Estimation of Soil Properties Using the Atlas of Australian Soils. CSIRO Land and Water, Canberra (Australia).

Payne, M., Chenhall, B.E., Murrie, M., Jones, B.G., 1997. Spatial variation of sedimentbound zinc, lead, copper and rubidium in Lake Illawarra, a coastal lagoon in eastern Australia. J. Coastal Res. 13, 1181-1191.

R Development Core Team, 2013. R: A language and environment for statistica computing. R Foundation for Statistical Computing, Vienna, Austria. <http:/ www.R-project.org >. ISBN 3-900051-07-0.

Roy, D.P., Peat, C., 1976. Bathymetry and Bottom Sediments of Tuross Estuary and Coila Lake. New South Wales Department of Mines.

Smith, S.A., 2001. Trace metal contamination of creek sediments along northern Lake Illawarra, NSW. BSc (Hons) Thesis, University of Wollongong.

Suh, J.-Y., Birch, G.F., 2005. Use of grain-size and elemental normalisation in the interpretation of trace metal concentrations in soils of the reclaimed area adjoining Port Jackson, Sydney, Australia. Water Air Soil Pollut. 160, 357-371.

Telford, K., Maher, W., Krikowa, F., Foster, S., 2008. Measurement of total antimony and antimony species in mine contaminated soils by ICPMS and HPLC-ICPMS. J. Environ. Monit. 10, 136-140.

TRUenergy Tallawarra, 2005. TRUenergy CLG Meeting. TRUenergy, Wollongong.

Tylmann, W., 2004. Estimating recent sedimentation rates using $210 \mathrm{~Pb}$ on the example of morphologically complex lake (Upper Lake Raduńskie, N Poland) Geochronometria 23, 21-26.

Yassini, I., 2004. Pulsative discharge of dissolved metals from copper slag emplacements into the Windang unconfined sandy aquifer adjacent to Lake Illawarra. Wetlands (Australia) 21, 253-267.

Yassini, I., Jones, B., 1987. Ostracoda in Lake Illawarra: environmental factors, assemblages and systematics. Mar. Freshwater Res. 38, 795-843.

Zhou, D., 1985. Adjustment of geochemical background by robust multivariate statistics. J. Geochem. Explor. 24, 207-222. 